\title{
UPAYA MENINGKATKAN HASIL BELAJAR DAN KEAKTIFAN SISWA MELALUI PENERAPAN MODEL PEMBELAJARAN KOOPERATIF TIME TOKEN PADA MATERI INTERAKSI MANUSIA DAN LINGKUNGAN DALAM DINAMIKA LITOSFER KELAS X IPS SMA TAMAN MADYA MALANG
}

\author{
1)Margareta Aprilia Wulandari; ${ }^{2}$ )Siti Halimatus Sakdiyah \\ Universitas Kanjuruhan Malang \\ Email: 1)wulanmargareta15793@gmail.com; ${ }^{2}$ sitihalimatus@unikama.ac.id
}

\begin{abstract}
Abstrak
Time Token, merupakan salah satu model pembelajaran kooperatif yang paling sederhana, dan merupakan model yang paling baik untuk permulaan bagi para guru yang baru menggunakan pendekatan kooperatif. Penelitian ini bertujuan untuk meningkatkan hasil belajar dan keaktifan belajar siswa kelas X SMA Taman Madya Malang melalui penerapan model pembelajaran Kooperatif Time Token. Berdasarkan hasil observasi dan tes uraian yang diberikan guru ketika proses pembelajaran berlangsung di kelas X IPS SMA Taman Madya Malang, serta informasi yang diperoleh dari guru matapelajaran Geografi dapat diketahui bahwa hasil belajar $40 \%$ dan keaktifan $24 \%$. Keaktifan yang rendah disebabkan oleh: 1) Siswa tidak memberikan pertanyaan ataupun pendapat pada saat guru memberikan kesempatan untuk bertanya; 2) siswa kurang percaya diri pada saat mempresentasikan Hasil diskusi didepan kelas; 3) Siswa jarang berargumen pada saat diskusi kelompok; 4) Rasa keingintauan siswa rendah, hal ini juga mempengaruhi hasil belajar yang rendah. Hasil observasi dilakukan melalui observasi di kelas X IPS SMA Taman Madya Malang, dengan jumlah 20 siswa. Berdasarkan observasi Hasil Belajar siswa dari 20 siswa hanya 8 siswa yang mecapai KKM dan 12 siswa yang lain tidak mencapai KKM. KKM yang ditetapkan di SMA Taman Madya Malang adalah 75. Sedangkan pada observasi Keaktifan Belajar, dari 20 siswa 11 siswa saja yang aktif dan 9 siswa lainnya tidak aktif. Rancangan penelitian ini menggunakan penelitian tindakan kelas model Kemmis dan Taggard. Penelitian dilakukan di SMA Taman Madya Malang siswa kelas X IPS, yang terdiri dari 20 siswa yaitu 18 lakilaki dan 2 perempuan. Nilai hasil belajar siswa kelas X IPS pada siklus I menunjukan dari 20 siswa yang tuntas 13 orang dengan presentase $65 \%$, dan nilai keaktifan belajar dengan presentase $73 \%$. Sedangkan nilai hasil belajar siklus II menunjukan siswa yang tuntas 17 orang dengan presentase $85 \%$, dan nilai keaktifan belajar siswa dengan presentase $96 \%$. Hasil penelitian dan pembahasan dapat ditarik kesimpulan bahwa penerapan model pembelajaran Kooperatif Time Token dapat meningkatkan hasil belajar dan keaktifan siswa kelas X IPS SMA Taman Madya Malang.
\end{abstract}

Kata Kunci : Time Token, hasil belajar, keaktifan

\section{PENDAHULUAN}

SMA Taman Madya Malang merupakan salah satu sekolah yang berada di kota Malang dan tidak jauh beda dengan sekolah lainnya yang ada di kota Malang. Sama dengan sekolah lainnya di SMA Taman Madya terdapat permasalahan pada pembelajaran kelas $\mathrm{X}$ IPS khususnya. Masalah yang harus diselesaikan di SMA Taman Madya
Malang khususnya pada kelas X IPS yaitu rendahnya hasil belajar dan keaktifan belajar siswa. Masalah tersebut disebabkan oleh beberapa hal, diantaranya siswa kelas X IPS kurang bersemangat dalam mengikuti pembelajaran, siswa tidak memberikan pertanyaan ataupun pendapat pada saat guru memberikan kesempatan untuk 
bertanya, siswa kurang percaya diri pada saat mempresentasikan hasil diskusi di depan kelas, siswa jarang berargumen pada saat diskusi kelompok, rasa keingintahuan siswa rendah, siswa kurang memperhatikan penjelasan guru, masih ada siswa yang suka berbicara sendiri dengan temannya dan masih ada yang ramai saat pembelajaran berlangsung.

Dari rendahnya hasil belajar dan keaktifan siswa tersebut itulah yang membuat guru berusaha mencari jalan keluar dari permasalahan tersebut. Salah satu solusinya adalah menggunakan pembelajaran kooperatif sebagai upaya untuk meningkatkan hasil belajar dan keaktifan siswa melalui penerapan model pembelajaran kooperatif Time Token diaplikasikan di kelas X IPS. Tujuan dari penelitian ini adalah untuk meningkatkan hasil belajar dan keaktifan siswa kelas X SMA Taman Madya Malang. Sudjana (2009) yang "menyatakan bahwa hasil belajar adalah bagian terpenting dalam pembelajaran. Mendefinisikan hasil belajar siswa pada hakikatnya adalah perubahan tingkah laku sebagai hasil belajar dalam pengertian yang lebih luas mencakup bidang kognitif, afektif, dan psikomotorik". Di myati (2009) "menyatakan segala pengetahuan harus diperoleh dengan pengamatan sendiri, pengalaman sendiri, penyelidikan sendiri, dengan bekerja sendiri, fasilitas yang diciptakan sendiri, baik secara rohani maupun teknik (Keaktifan belajar).

Model pembelajaran Time Token Arends (1998) merupakan model pembelajaran yang bertujuan agar masing-masing anggota kelompok diskusi mendapatkan kesempatan untuk memberikan konstribusi dalam menyampaikan pendapat mereka dan mendengarkan pandangan serta pemikiran anggota lain. Kurniasih (2015) model pembelajaran Time Token merupakan salah satu contoh kecil dari penerapan pembelajaran demokratis di sekolah.

\section{METODE PENELITIAN}

Penelitian ini dirancang dengan menggunakan penelitian tindakan kelas (PTK). Model ini terdiri dari siklussiklus yang paling berhubungan dimana masing-masing siklus terdiri dari beberapa tahapan: (1) rencana tindakan, (2) pelaksanaan tindakan, (3) observasi (pengamatan), (4) refleksi, apabila siklus I belum mencapai tujuan yang ditargetkan, maka dilanjutkan dengan siklus II yaitu perbaikan rencana, pelaksanaan tindakan, obesrvasi dan refleksi. Apabila siklus II juga belum mencapai target maka dilanjutkan dengan siklus berikutnya yang selalu dimulai dengan perbaikan tindakan dari siklus sebelumnya.

Penelitian ini dilaksanakan di SMA Taman Madya Malang pada semester genap. Kehadiran peneliti di lapangan sangat diperlukan, karena sebagai perencana tindakan, pengumpul data, dan pelapor hasil penelitian. Selain itu guru juga berperan sebagai penyusun bahan ajar (lembar kegiatan), pelaksana tindakan (pengajar/guru), dan pembuat laporan hasil penelitian yang dilakukan. Sedangkan observer dari teman sejawat bertindak sebagai pengamat selama pembelajaran berlangsung.

Pada penelitian ini yang menjadi subjek penelitian adalah siswa kelas X IPS di SMA Taman Madya Malang dengan jumlah siswa 20 orang, yang terdiri dari 18 siswa laki-laki dan 2 siswa perempuan dengan alamat jalan Serayu Utara No 14 Belimbing, Kabupaten Malang, Jawa Timur. Adapun instrumen 
yang digunakan yaitu: lembar observasi lembar pengamatan yang diisi oleh observer, tes digunakan untuk mengukur kemampuan siswa dalam menganalisis materi pelajaran yang diberikan, dan catatan lapangan untuk melengkapi data yang belum terekam pada lembar observasi selama pembelajaran berlansung. Hal ini dilakukan untuk mengetahui aktifitas siswa selama proses pembelajaran berlangsung. Rencana pelaksanaan pembelajaran (RPP) yang dipakai guru adalah rencana pelaksanaan pembelajaran K13.

Instrumen penelitian yang digunakan tes hasil belajar dan keaktifan siswa, sederetan pertanyaan, lembar kerja yang dapat digunakan untuk mengukur pengetahuan, keterampilan, bakat dan kemampuan dari subjek penelitian, dan diskusi kelompok. Lembaran ini berisi soal-soal esai untuk mengukur hasil belajar siswa. Pemberian tes hasil belajar yang akan dilakukan dalam penelitian dimaksudkan untuk mengukur seberapa jauh hasil yang diperoleh siswa setelah pemberian tindakan kelas. Lembar observasi, untuk mengetahui aktivitas siswa yang dilakukan dengan cara mengamati perilaku siswa selama kegiatan belajar mengajar maupun kegiatan kelompok dengan cara memberikan tanda checklist pada lembar observasi yang telah dipersiapkan. Catatan lapangan, merupakan alat yang sangat penting dalam Penelitian Tindakan Kelas untuk memperoleh data. Tujuan dibuat catatan lapangan untuk melengkapi data yang belum terekam pada lembar observasi selama pembelajaran berlangsung. Catatan ini mencakup semua keaktifan pembelajaran baik interaksi siswa dengan guru, interaksi siswa dengan kelompoknya maupun secara klasikal.
Data yang dikumpulkan dalam penelitian ini data hasil belajar dan keaktifan yang diperoleh dan hasil pekerjaan siswa menyelesaikan tes, data keterlaksanaan model pembelajaran Time Token, dan catatan lapangan hasil pengamatan yang berkaitan dengan hasil belajar dan keaktifan siswa dalam pembelajaran.

Analisis data hasil belajar dengan menghitung peningkatan hasil belajar siswa dengan cara menilai tes ulangan harian dilakukan menghitung jumlah siswa yang tuntas. Analisis data dilakukan pada akhir pembelajaran untuk memperoleh data hasil belajar siswa. Rumus cara menghitung nilai hasil belajar

$$
\text { Nilai }=\frac{\text { Jumlah siswa yang tuntas }}{\text { Jumlah siswa keseluruhan }} \times 100 \%
$$

Analisis keaktifan siswa dengan menghitung skor perolehan. Analisis keaktifan dilakukan selama pembelajaran berlangsung. Rumus cara menghitung nilai keaktifan siswa

$\mathrm{N}=\frac{\text { Skor perolehan }}{\text { Skor } \text { maksimum }} \mathrm{X} 100 \%$

\section{HASIL DAN PEMBAHASAN}

Paparan tindakan pelaksanaan tindakan meliputi tahapan perancanaan, pelaksanaan, observasi, dan refleksi. Pada penelitian ini, pelaksanaan tindakan dalam dua siklus yaitu siklus tindakan I dan siklus tindakan II. Pra tindakan penelitian dilakukan melalui observasi di kelas X IPS, dengan jumlah 20 siswa. Berdasarkan hasil observasi hasil belajar siswa, dari 20 siswa hanya 8 siswa saja yang tuntas sedangkan 12 siswa yang tidak tuntas. KKM yang ditetapkan di SMA Taman Madya Malang adalah 75 sebagian besar siswa masih mendapat nilai dibawah KKM. 
Sedangkan hasil observasi keaktifan siswa hanya $24 \%$ saja yang aktif. Hal ini disebabkan: (1) kemampuan menguasai materi siswa kurang, sehingga pada saat guru memberikan umpan balik hanya siswa tertentu saja yang aktif dan kondisi kelas menjadi pasif, (2) kelas X IPS ini termasuk kelas yang masih dikategorikan siswanya belum berani menyampaikan pendapatnya, (3) Kelas $X$ IPS termasuk kelas yang hasil belajarnya rendah, dimana hanya beberapa siswa yang tuntas dalam belajarnya, (4) Pada waktu diskusi kelompok hanya sebagian siswa yang aktif karena kurangnya rasa tanggung jawab dari masing-masing siswa dan kurangnya kerjasama yang baik antara siswa untuk saling belajar sehingga proses berpikir siswa belum terbangun dengan baik dan hasil belajar siswa belum tercapai secara optimal.

Hasil observasi siklus I kegiatan observasi yang dilakukan pada siklus I menyangkut pelaksanaan pembelajaran yang sudah dilaksanakan pada instrumen penelitian. Guru dibantu obsever mengobservasi kegiatan belajar mengajar, apakah terdapat temuan yang menyangkut kegiatan penelitian. Adapun hasil observasi pelaksanaan tindakan siklus I antara lain sebagai berikut: Hasil catatan temuan lapangan, obsever mencatat temuan-temuan mengenai hal-hal yang berkenan dengan proses belajar mengajar pada model pembelajaran Time Token.

Obsever membuat catatan temuan lapangan tersebut untuk mendapatkan informasi yang lengkap mengenai proses belajar mengajar yang sedang berlangsung. Hasil catatan lapangan tersebut selanjutnya dianalisis mana saja yang dibutuhkan atau tidak sesuai sebagai pedoman observasi, yang nantinya akan diperbaiki disiklus berikutnya.

Refleksi Berdasarkan hasil observasi yang ditemukan, guru dapat mengetahui bahwa proses pembelajaran yang telah dilakukan pada siklus I banyak sekali mengalami siklus kekurangan. Kekurangan-kekurangan ini merupakan dasar rencana perbaikan siklus II adalah sebagai berikut: Guru harus lebih memotivasi siswa pada awal pembelajaran untuk lebih bersemangat, aktif dan berani mengemukakan pendapat, Guru menjelaskan kepada siswa tentang langkah-langkah model pembelajaran Time Token secara terperinci, agar proses pembelajaran sesuai dengan apa yang diinginkan oleh guru.

Hasil observasi siklus II Pada pelaksanaan observasi terhadap pelaksanaan tindakan siklus II pertemuan kedua menunjukan guru telah mampu melaksanakan pembelajaran dengan baik. Secara umum pelaksanaan tindakan sudah sesuai pembelajaran yang telah dibuat. Semua tahapan kegiatan pembelajaran yang mengacu pada langkah-langkah model pembelajaran Time Token telah dilaksanakan dengan sempurna oleh guru. Keterlaksanaan model pembelajaran dapat dipaparkan sebagai berikut: Catatan temuan lapangan Obsever mencatat temuan-temuan mengenai hal-hal yang berkenan dengan proses belajar mengajar pada model pembelajaran kooperatif Time Token. Obsever membuat catatan lapangan tersebut untuk mendapatkan informasi yang lengkap mengenai proses belajar mengajar yang sedang berlangsung. Hasil catatan lapangan tersebut dilakukan perbaikan mana saja yang perlu diperbaiki dari siklus I. Hasil observasi dari lembar keterlaksanaan 
model pembelajaran kooperatif Time Token.

Berdasarkan observasi yang telah dilaksanakan dengan menggunakan model pembelajaran kooperatif Time Token diperoleh hasil sebagai berikut:

Siswa sudah terbiasa dengan model pembelajaran Time Token, siswa memahami isi materi pelajaran yang sedang dibahas, siswa semangat dan termotivasi untuk belajar dan berusaha untuk mendapatkan nilai yang baik dari hasil nilai sebelumnya.

Data keterlaksanaan model pembelajaran kooperatif Time Token diperoleh melalui lembar observasi dan diamati langsung oleh obsever. Data keterlaksanaan pembelajaran kemudian diolah. Rumus untuk menghitung keterlaksanaan model pembelajaran kooperatif Time Token yaitu keterlaksanaan model sama dengan jumlah skor yang diperoleh dibagi jumlah skor total dikali dengan seratus persen.

Keterlaksanaan pembelajaran dikategorikan terlaksana. Hal ini terlihat dari keantusiasan siswa dalam mengikuti proses model pembelajaran kooperatif Time Token.

Keterlaksanaan model pembelajaran kooperatif Time Token pada siklus I dikategorikan kurang terlaksana, sedangkan keterlaksanaan model pembelajaran kooperatif Time Token siklus II terlaksana. Keterlaksanaan model pembelajaran kooperatif Time Token dari siklus I ke siklus II sudah terlihat jelas ada peningkatan.

Kegiatan refleksi pada siklus II ini adalah akhir dari perencanaan penelitian diterapkannya model pembelajaran kooperatif Time Token. Guru telah mengetahui letak keberhasilan dari model pembelajaran yang telah diterapkan. Sehingga guru menarik kesimpulan bahwa keterlaksanaan model pembelajaran kooperatif Time Token dapat terlaksana dengan baik.

\section{Tabel 1. Hasil Belajar Siklus I}

\begin{tabular}{lcc}
\hline $\begin{array}{l}\text { Ketuntasan } \\
\text { belajar }\end{array}$ & $\begin{array}{l}\text { Siswa } \\
\text { lulus } \\
\text { KKM }\end{array}$ & Presentase \\
\hline Siklus I & 13 & $65 \%$ \\
\hline
\end{tabular}

Berdasarkan nilai hasil belajar yang ada pada tabel 1 menjelaskan bahwa nilai pada siklus I menunjukkan 7 dari 20 siswa yang belum tuntas. Sedangkan 13 siswa lainnya mendapatkan nilai di atas KKM dengan presentase $65 \%$ kategori tidak tuntas. Dengan demikian perlu dilakukan perbaikan pembelajaran pada Siklus II

\section{Tabel 2. Hasil Belajar Siklus II}

\begin{tabular}{lll}
\hline $\begin{array}{l}\text { Ketuntasan } \\
\text { belajar }\end{array}$ & $\begin{array}{l}\text { Siswa } \\
\text { lulus } \\
\text { KKM }\end{array}$ & Presentase \\
\hline Siklus I & 13 & $65 \%$ \\
Siklus II & 17 & $85 \%$ \\
\hline
\end{tabular}

Berdasarkan nilai hasil belajar yang ada pada tabel 1 menjelaskan bahwa nilai hasil belajar siklus I siswa yang sudah lulus KKM 13 siswa dengan presentase $65 \%$ kategori tidak tuntas dan siklus II siswa yang sudah lulus KKM 17 siswa dengan presentase $85 \%$ kategori tuntas. Berdasarkan uraian diatas dapat simpulkan bahwa hasil belajar sudah meningkat dibandingkan hasil belajar yang ada pada siklus I. Untuk hasil belajar pada siklus II sudah sesuai dengan apa yang diharapkan oleh guru.

Sedangkan pada keaktifan siswa pada siklus I guru juga menarik kesimpulan bahwa model pembelajaran kooperatif Time Token dapat terlaksana dengan baik. 
Tabel 3. Hasil Keaktifan Siswa Siklus I

\begin{tabular}{ll}
\hline $\begin{array}{l}\text { Ketuntasan } \\
\text { Keaktifan }\end{array}$ & Presentase \\
\hline Siklus I & $73 \%$ \\
\hline
\end{tabular}

Berdasarkan nilai keaktifan belajar siklus I yang ada pada tabel 3 menunjukan $73 \%$ dengan kategori rendah. Dengan demikian perlu dilakukan perbaikan pembelajaran pada siklus II

Tabel 4 Hasil Keaktifan Siswa Siklus II

\begin{tabular}{ll}
\hline $\begin{array}{l}\text { Ketuntasan } \\
\text { Keaktifan }\end{array}$ & Presentase \\
\hline Siklus I & $73 \%$ \\
Siklus II & $96 \%$ \\
\hline
\end{tabular}

Berdasarkan nilai keaktifan siswa yang ada pada tabel 4 menunjukan bahawa nilai keaktifan siklus I masuk kategori rendah sedangkan pada siklus II masuk kategori tinggi.

Berdasarkan deskripsi tindakan dan data serta analisis yang telah dilakukan, dikemukakan temuan penelitian sebagai berikut:

\section{Temuan Silkus I}

Berdasarkan hasil temuan lapangan yaitu: siswa sibuk sendiri pada saat guru membuka pelajaran, situasi masi ramai saat pembelajaran berlangsung dan saat pembagian diskusi kelompok, ada kelompok yang tidak bekerja sama pada saat diskusi, pada saat diskusi hanya beberapa siswa saja yang mendominasi ada juga siswa yang jalan-jalan saat diskusi sedang berlangsung, dan sebagian siswa kurang percaya diri dalam mengisi soal hal ini dapat dilihat pada saat siswa mengerjakan soal, siswa masih suka untuk meminta jawaban dari teman sebangku dan membuka buku.
2. Temuan Silkus II

Keterlaksanaan tindakan untuk penelitian pada siklus II memiliki ketercapaian hasil belajar yaitu: siswa tenang dan mendengarkan penjelasan guru, kerja sama dalam kelompok sangat baik, siswa aktif dalam kegiatan berdiskusi, pada saat tes siswa tidak melakukan kecurangan.

Hasil belajar siswa kelas X IPS sebelum dilakukan penelitian siswa yang lulus KKM berdasarkan hasil pra tindakan adalah $40 \%$ siswa, pada siklus I $65 \%$ (13) siswa dengan nilai rata-rata 75 , dan pada siklus II 85\% (18) siswa dengan nilai rata-rata 85 . Meningkatnya hasil belajar siswa kelas X IPS SMA Taman Madya Malang di karenakan pembelajaran yang menghadapkan siswa pada masalah dunia nyata yang dapat memberikan kondisi belajar aktif kepada siswa Arends (dalam Trianto, 2007).

Keaktifan siswa kelas X IPS sebelum dilakukan penelitian siswa yang aktif adalah $24 \%$, pada siklus I $73 \%$, dan pada siklus II 96\%. Segala pengetahuan harus diperoleh dengan pengamatan sendiri, pengalaman sendiri, penyelidikan sendiri, dengan bekerja sendiri, fasilitas yang diciptakan sendiri, baik secara rohani maupun teknik Dimyati (2009).

Adapun tujuan yang hendak dicapai dalam pembelajaran kooperatif Time Token yaitu: bukanlah penyampaian sejumlah pengetahuan siswa melainkan pembelajaran yang bertujuan agar masing-masing anggota kelompok diskusi mendapatkan kesempatan untuk memberikan konstribusi dalam menyampaikan pendapat mereka dan mendengarkan pandangan serta pemikiran anggota lain, dan sekaligus mengembangkan kemampuan siswa untuk secara aktif membangun 
pengetahuan sendiri serta membantu peningkatan motivasi dalam belajar dan lebih aktif dalam kegiatan pembelajaran.

Peningkatan hasil belajar siswa kelas $\mathrm{X}$ IPS SMA Taman Madya Malang terjadi karena guru melakukan perbaikan dalam pembelajaran, guru memperbaiki cara penyampaian meteri secara garis besar. Meningkatnya hasil belajar siswa kelas $X$ IPS SMA Taman Madya Malang dikarenakan pembelajaran yang menghadapkan siswa pada masalah dunia nyata yang dapat memberikan kondisi belajar aktif kepada siswa Arends (dalam Trianto2007).

Selain itu keunggulan dari model pembelajaran kooperatif Time Token yaitu guru mempunyai tugas untuk selalu melibatkan siswa untuk menemukan berbagai solusi bersama sama terhadap pemecahan permasalahan yang ada. Adapun kekurangan dari model ini yaitu: hanya dapat digunakan untuk mata pelajaran tertentu saja seperti tidak dapat digunakan dalam mata pelajaran yang berunsur filosofi.

Pra tindakan penelitian dilakukan melalui observasi di kelas X IPS, dengan jumlah 20 siswa. Berdasarkan hasil observasi, dari 20 siswa hanya 8 siswa saja yang tuntas sedangkan 12 siswa yang tidak tuntas. KKM yang ditetapkan di sma Taman Madya Malang 75 sebagian besar siswa mendapat nilai di bawah KKM. peningkatan hasil belajar siklus I dengan menggunakan model pembelajaran kooperatif Time Token. Siklus I berlangsung II kali pertemuan yakni 3 jam pelajaran, pertemuan pertama 2 jam pelajaran yang dilaksanakan pada tanggal 6 Februari 2018, dan pertemuan kedua 1 jam pelajaran pada tanggal 8 februari 2018. Guru menjelaskan materi sesuai dengan pelaksanaan pembelajaran. Dilihat dari hasil belajar dan keaktifan pada pra tindakan belum memenuhi KKM, maka guru melakukan tes hasil belajar terhadap siklus I dapat dilihat dari 20 siswa yang tuntas hanya 13 siswa dengan persentase ketuntasan $65 \%$ dan rata-rata nilai 75 sedangkan 7 siswa lainnya belum mencapai KKM, dan nilai hasil keaktifan pada siklus I 73\%. Dimyati (2006) "menyatakan bahwa hasil belajar hasil dari suatu interaksi tindak belajar dan tindak mengajar. Dari sisi guru, tindak mengajar diakhiri dengan proses evaluasi hasil belajar. Sedangkan dari sisi siswa hasil belajar adalah merupakan berakhirnya pengajaran dari puncak proses belajar".

Lembar observasi keterlaksanaan model pembelajaran pada lembar observasi keterlaksanaan model pembelajaran pada siklus I hasilnya sudah baik, tetapi masih perlu perbaikan pada siklus II dimana skor yang diperoleh pada siklus I sebesar $72 \%$.

Peningkatan hasil belajar siklus II dengan menggunakan model pembelajaran kooperatif Time Token Hasil belajar pada siklus II telah mengalami peningkatan dibanding dengan hasil belajar siklus I. Nilai hasil belajar pada siklus II rata-rata yang diperoleh 85 dan persentase $88 \%$, dan nilai keaktifan siklus II $96 \%$. Penelitian ini didukung oleh hasil belajar dan keaktifan dijadikan parameter untuk mengukur kemampuan siswa. Hasil belajar yang berupa nilai dijadikan bukti sebagai pencapaian proses belajar dan syarat untuk melanjutkan ke jenjang berikutnya ataupun sebagai syarat untuk melakukan pekerjaan tertentu. Lembar observasi keterlaksanaan model pembelajaran Pada lembar observasi siklus II sudah mengalami perubahan dimana guru memperbaiki semua kekurangan yang ada pada siklus I. 
Hasil yang diperoleh pada lembar observasi keterlaksanaan model siklus II $95 \%$.

\section{KESIMPULAN}

Berdasarkan penelitian yang dilakukan, guru dapat menarik hasil kesimpulan bahwa pembelajaran dengan penerapan model pembelajaran kooperatif Time Token pada pelajaran Geografi pokok bahasan interaksi manusia dan lingkungan dalam dinamika litosfer (tektonisme dan vulkanisme). Pada siklus I yang mendapatkan dengan kategori sangat tinggi 3 siswa, 10 siswa mendapatkan kategori tinggi, 5 mendapatkan ketgori sedang dan 2 orang siswa mendapat kategori rendah. Sedangkan hasil keaktifan siswa pada siklus I 73\% masuk kategori sedang. Pada siklus II 15 orang siswa mendapat kategori sangat tinggi, 5 orang siswa mendapat kategori tinggi. Sedangkan pada keaktifan siswa siklus II 96\% masuk kategori tinggi. Jadi ada peningkatan antara siklus I dan siklus II.

\section{DAFTAR RUJUKAN}

Arends. $1998 . \quad$ Model-model Pembelajaran Inovatif Berorientasi Konstuktivitis, Jakarta

Dimyati. 2006. Belajar dan Pembelajaran. Jakarta: PT Rineka Cipta.

Dimyati dan Mudjiono. 2009. Belajar dan Pembelajaran. Jakarta: PT Rineka Cipta.

Kurniasih. 2015. Ragam

Pengembangan

Model

Pembelajaran. Kata Pena.

Jakarta.

Sudjana, Nana. 2009. Penilaian Hasil Proses Belajar Mengajar. Bandung: PT Remaja Rodakarya.

Trianto. 2007. Model-Model Pembelajaran Inovatif Berorientasi Konstruktivistik Jakarta: Prestasi Pustaka. 